\title{
The arts of the remix: ethnography and rap
}

By Brett Lashua (Cardiff University)

In this paper I take note of 'the arts of the remix', in which techniques of producing hip-hop music with First Nations young people in Canada involved remixing both music and research practices. Through a school-based leisure programme called The Beat of Boyle Street, I taught Aboriginal young people to use computers and audio software to make, produce, and record their own hip-hop music. The programme's research component involved a bricolage of artsbased and performance ethnographic techniques and analyses. The shared music-making process opened space for storytelling, and the songs that were produced articulated many of the struggles and hopes of First Nations youth.

\section{The arts of the remix: ethnography and rap}

In a rap called Turning Point, the First Nations ${ }^{1}$ rapper MC Sound (age 20), one of the participants in the research programme I will present here, sang: ${ }^{2}$

Yo, there's a problem of an issue,

I told you we as Natives can't wipe away with tissue

an eternal wound and itch too, there isn't a doctor to stitch you

they ditch you, for the cash, fool, at least $50 \%$ of society is cool

like my man too, taught me in school, to do what I can to help you.

Who says we can't make a change?

helping the north, the reserves, in the rural life that's strange

so we try to identify blocks, tell people with children 'stop smoking rocks!'

and the flocks of life's lost clients, want to relieve the long overdrawn silence

contributing to some sort of alliance, instead of resorting to violence

'cause that's just a minus.

This rap offers insights into the politics, concerns, and dreams of urban AboriginalCanadian youth: confronting racism, seeking respectful and relevant educational opportunities in spite of disintegrating traditional community and familial ties, and hoping to build upon cultural strengths while continuing to struggle with poverty, drugs and alcohol abuse, and violence. MC Sound's song offers a 'turn in a conversation' (Bochner and Ellis 2003:507) and an invitation to teach, learn and ally ourselves with young people.

\footnotetext{
1 'First Nations' and 'Aboriginal' are preferred terms for most indigenous people of Canada. The young people in the project used them interchangeably.

To listen to the audio tracks discussed in this paper, read the html version at www.anthropologymatters.com/journal
} 
In this spirit, this paper discusses sharing music and music-making processes with young people through my doctoral research with The Beat of Boyle Street - a leisure programme through which I taught young Aboriginal people to use computers and audio software to make, produce, and record their own hip-hop music (Lashua 2005). My connection and involvement with these creative processes was crucial to improve my understanding of the significance of music to participants. MC Sound's rap begins to open up questions of why this programme was valuable to young people, as well as important to people who do research and work with youth.

My arts-based research methods draw further from my musical experiences as a drummer, performer, audio producer, leisure practitioner, and youth group leader, and intersect with young people's interests, passions, and talents for rapping, dancing, and creative expression. These may at first seem an odd combination for research. However, Andy Bennett noted that the 'traditional' tools researchers have 'conventionally' relied upon to study youth musical cultures have often 'produced explanations far removed from those young people for whom music "matters" on a day-to-day basis' (2003:197). Bennett's research raises questions about the ways that research has explored, valued, and attempted to understand relationships between popular music and young people: How well do existing social scientific research methods adequately capture the meaningful relationships and contexts of music? Music-making allowed me to enter into creative processes with young people, to explore naturalised and often taken-for-granted issues around music and meaning, creation and consumption. Performing an ethnographic study of a music-making leisure programme further allowed me to gain a deeper understanding of the value and spaces of music and leisure in young people's everyday lives, and to take part - to some extent - in the creative production of youth musical cultures (Cohen and Ainley 2000).

\section{The Beat of Boyle Street}

In Canada, the voices and views of Aboriginal people have largely gone unheard outside of indigenous communities. Representations of Aboriginal people have historically been controlled by the government, and have been based on geographical and genetic identification markers (such as which Nation or reserve one hails from, or status based on bloodlines), as well as presumed, dominant Franco-English Canadian norms and values. Aboriginal people who move to urban areas are often left outside of band, mainstream or governmental services. Urban centres, however, have the largest growing population of Aboriginal people, and many of these are young: over $50 \%$ of Canada's Aboriginal population is under 25 years old, and over 50\% now reside in cities (Statistics Canada 2001).

The Beat of Boyle Street is a collaborative programme between the University of Alberta and the Boyle Street Education Centre (BSEC). (The name of the school is used with permission.) The Beat of Boyle Street music programme continues in operation, and has recently expanded to include evening programmes at a youth centre BSEC is part of a community co-op providing basic social services for people in need in Edmonton's inner city neighbourhoods, and its mandate is to re-engage 'at risk' and out-of-school youth (ages 14-20) in education processes. With an enrolment of around 100 students, over $90 \%$ of whom report Aboriginal heritage, the school addresses concerns of urban poverty and youth homelessness, the loss of traditional communal and familial cultural bonds, drug and alcohol use and addictions, gang 
involvement, and crime (for example, $65 \%$ of students have been arrested), as well as victimisation resulting from violence, effects of poor parenting, teen pregnancy and teen parenting, and consequences of racism towards First Nations people. Often as a corollary to these concerns, most students report gaps in their education ranging from a few months to several years. One student, a young woman who calls herself LiGhTsWiTcH (age 15), created a spoken-word poem, Broken Home, which expressed many of these realities:

Broken home full of anger and pain

Full of bruises and cuts and beer and such

Full of suicidal thoughts and murderous minds

Full of drugs and slaps and punches thrown

Full of greed and hurt and full of unknown sitters and misunderstanding shit

Full of rape and no freedom to get away

Full of dishonesty and mistrust

Full of racism and hate

Full of screams and shouts and 'get the hell out's'

Full of sex and loud music and parties every night

Then suddenly, its over, it all comes to an end...

When the littlest one pulls a gun to her head.

For many Aboriginal youth, hip-hop culture articulates the issues and struggles in their lives (Efron 2001, Hollands 2004, Sakolsky 1995). The Beat of Boyle Street engaged with young people by offering access to tools and technology to make their own music, remixes, raps, spoken-word poetry, and hip-hop dance tracks. The programme was designed as a re-engagement strategy for students attending the school, as well as to provide a platform for my doctoral research into popular culture and the musical leisure practices of urban youth. The research also asked how scholarpractitioners may treat musical processes as ethnographic research material. In the aggregate, I refer to these processes as 'remixology' - a term coined by one of the participants in the programme to describe musical remixes and 'mash ups' - and which I came to consider within broader cultural and research frames as the arts of the remix.

For many students such as LiGhTsWiTcH and MC Sound, music is a passion, and The Beat of Boyle Street created a variety of ways to support and affirm the place and value of leisure and popular culture in their lives. Young people in the programme frequently voiced the sentiment that making music or writing lyrics was the most significant involvement that sustained them through their days. During an interview with CBC radio on March 10th, 2003, MC Sound announced:

I used to be a pugilist, solve my problems with fists, but that's in the midst, you know? So I took it to passion and fashion and started writing rhyme after rhyme through poetry on loose-leaf line. This is what I like to do; I don't commit no crime, though my people are behind bars at the Remand [detention centre in Edmonton] doing time. But, I just keep doing my passion you know? And just keep going, keep going.

These words emphasise some of the tensions in rap music as performed by many urban Aboriginal youth, at times operating in-between attempts to turn away from 
what were deemed negative influences (both outside and within the Aboriginal community), and investing themselves in creative pastimes such as music and art. While we were working on one track, a young man shared with me a list of ' 10 things I can do to stay out of trouble today'; at the top of the list was 'write lyrics'. Yet doing rap music also clearly involved attempts by young people to necessarily reproduce some of the harder-edged attitudes, styles and behaviours notorious in playing the rap 'game'. In relation to this, Greg Dimitriadis has noted:

I came to see the kind of urgency young people (especially young men) invested in rap music and its often problematic images and messages in very different ways. I came to see their use of rap music, their constructions of invulnerable icons, their constructions of community, as one node in a much larger elaboration of resources for survival upon which young people drew. (2001b:593)

According to Tomlinson (2006), leisure pursuits such as making music provide key ways of coping, offering spaces for creating meanings in spheres over which people have some sense of control. Most of the young people who attend Boyle Street Education Centre have few opportunities to participate in creative leisure activities. The programme provided young people with some choice over how to use the space - a dedicated music studio - e.g. to create beats, record rhymes, spin and scratch records, experiment with sounds, talk about favourite musical artists with me and their peers, and often just relax and listen to music. Importantly, The Beat of Boyle Street programme was initiated by young people - the students at BSEC asked for a music class to make rap music. Prior to my involvement, the school offered occasional short workshops with visiting musicians, but on the whole, young people did not have access to the technology or instruction for producing their own music.

My involvement took me to BSEC four hours a day, four days a week, across three years. In the 'music studio' (first an orange-tiled room in a back corner of the basement at the community co-op, and later in purpose-built music rooms in a new school building), I worked each day with two groups of six young people, 'playing' together to learn how to use audio production software to make and record our own raps and remixes. Overall, I made music with over 150 young people during my time at the school. The programme also provided new skills (with computers, software, and audio equipment) while valuing the ('street') skills that students already possessed. For example, students who had difficulty with reading and written text might nevertheless create freestyle rhymes rich in vocabulary, and might rap extemporaneously with ease. In general, the programme made coming to school a more positive experience for students - a point of particular importance for those who had not typically had success in schools.

\section{In the music room: thug country}

The programme centred upon making music with audio production software, most often in the form of a remix. There is no prescriptive way or method for making a musical remix. The audio production software ${ }^{3}$ that we used to create remixes

\footnotetext{
${ }^{3}$ We primarily used Sonic Foundry's Sound Forge and Acid Pro, Fruity Loops, and Propellerhead's Reason production software in The Beat of Boyle Street. While the software is somewhat specialised and ranged in cost from around \$200 to \$500 (Canadian), it was loaded on generic computers (PCs) running Microsoft Windows platforms. Apple/Mac computers currently come with a standard programme, 'Garageband', which offers similar functionalities.
} 
afforded possibilities nearly as limitless as our imaginations. Often, we began creating remixes using pre-recorded samples. In pop music, and particularly hip-hop, 'sampling' refers to taking a section of a song or a sound and copying it for use in another composition. For example, a sample of drum beat from one song may be copied and used in another song. Although sampling remains contentious in the ongoing debate about musical authorship and originality (Cutler 1995, Lipsitz 1994, Rojek 2005, Théberge 1997), the technique introduced young people to making music and provided immediately successful results - an important point when working with young people who have not had success in learning environments. Furthermore, sampling allowed participants to immediately begin to build new compositions to express their views, experiences, and emotions.

For instance, one participant's remix - this 'remixologist' goes by the nickname Patches - was composed of samples from a Tupac Shakur rap song, Changes (itself a remix of the Bruce Hornsby \& The Range song That's Just the Way It Is), and a country tune, Makin' Believe by Merle Haggard and George Jones. The young man who created this somewhat jarring, yet innovative juxtaposition dubbed the style 'thug country'. That is, the composition creatively blended his interests in urban hardcore 'gangsta' rap and the kinds of country western music that he grew up listening to on his First Nations reserve in rural Alberta. These compositions 'mashed' together to create a poignant lyrical collage. Tupac's rap begins: 'I see no changes, wake up in the morning and I ask myself, is life worth living or should I blast myself? I'm tired of being poor and even worse I'm Black...', and incorporates Hornsby's original lyrics for the chorus, 'That's just the way it is'. Patches wanted the chorus from Makin' Believe to respond to Tupac's verse: 'I'm just makin' believe, what else can I do?'

Working together side by side at the computer workstation, Patches and I shared stories as we previewed and selected songs to cut into samples. We asked one another questions: How did we connect with this song? How did that song evoke childhood places? Why remix such seemingly disparate styles? In what ways did both songs share meanings around struggling with hope, dreams, and illusions of a better life? Instead of just 'makin' believe', what else could we do? How did coming to school change his outlooks for the future? Was making music and leisure important? We shared a laugh as we heard the results of our creative processes. We experimented with special effects, different arrangements, and other sampled beats and rhythms. When he was sufficiently pleased with the sonic results, Patches created a compilation CD including our 'thug country remix' and other favourites to play over the weekend for his friends. I made a CD copy to share with friends too.

\section{Cultural histories and meanings: pimpin'}

Technology has dramatically altered the ways that people make, consume, and understand music (Rojek 2005, Théberge 1997). In The Beat of Boyle Street, music was made in a seemingly unconventional way. Rather than 'traditional' instruments such as guitars and pianos, I supplied audio production software (sound editors, beat generators, multi-track sequencers, and synthesizers) and instructed young people in its use. For instance, after mixing a sample from Bizet's Carmen Suite with a drum loop from a funky James Brown song, then slowing the audio to a sauntering pace, BSEC students erupted in a collective chorus to tell me that the result was 'pimpin'. This, they explained, meant that it was suitable for cruising slowly in a car with friends on warm summer nights with the windows down and the music turned up. In 
ways such as this, music has the potential to evoke powerful scenes and emotions, intone a variety of social connections, and resonate with contestations and tensions in power relationships. This latter point was made plain to me as I asked the students if I would be 'pimpin'" if I cruised around listening to this composition. 'No way!' they shouted and laughed.

While I could show young people how to produce music to sound and feel the way they wanted it to feel, music remains contextual in both its meanings and uses. The musical play in The Beat of Boyle Street may have momentarily connected us, via the shared production space of the computer workstation, and the (somewhat) shared affect of the sound or groove of the track we produced-which meant that I could help the students to do something that they had much interest in doing. Yet how the songs we made were connected back into cultural contexts, histories, and meanings meant that our connections were tenuous and only ever went so far. To most students, though I was often amicably called the 'music dude' or 'the mixologist', I remained marked by difference in terms of my age (early 30s), my whiteness, my education and income (as a postgraduate student), and my position of power as a 'teacher' (no matter how firmly I stressed that I was not a teacher, but a specially contracted musician/researcher). Things, as such, are not necessarily, or infinitely, 'remixable'.

\section{Bricolage and stitching}

The arts of the remix share some affinities with notions of hybridity and bricolage. Concordant with notions of sampling, popular cultural theorists such as Bennett (2005), Dimitriadis (2001a), Fiske (1989), Giroux (1992), Sweetman (2001), and Willis (2000) have argued that young people make and re-make culture through appropriating the cultural 'raw materials' of life in order to construct meaning in their own specific cultural localities. In a sense, they are 'sampling' from broader popular culture and reworking what they can take into their own specific local cultures. That is, the ways that young people sample drum rhythms and vocal segments from songs may be thought of as analogous to the ways that they sample from broader cultures (such as styles from USA hip-hop cultures), modify or restructure it in some meaningful ways, and rework the 'compositions' of their own daily lives, including notions of identities.

This kind of stitching or composing was described by a young man (age 20) - a breakdancer, DJ, graffiti artist, and beatboxer-who goes by the name Kree-Azn. Kree-Azn recorded his thoughts on hip-hop in the music room, during a group demonstration of how to use a microphone and a get a good recording level. We used his lines-with permission - in later sonic collages and soundscape compositions:

Hip-hop made me the person who I am today. I think I'd be selling drugs, I'd be in jail, or either I'd probably be dead right now without that stuff. And I'm not one of those gangstas, I'm not a negative person, I'm straight-up positive. Yeah, that's who I be, I'm half Native and half Vietnamese. So, my boy was sitting there, and he knew that I was half Native and half Asian, he was like, 'yo, you know what would be a sick name for you? Kree-Azn'. You know? Like, a word 'creative', like 'creation' or two races that click together, you know, like, it does the same thing with hip-hop, like, there's no certain race you have to be in hip-hop, there's no certain skin colour, it's all about what's inside you, the creativity. 
Kree-Azn's ongoing hybrid identity work remixes his Cree First Nations heritage with his Asian roots, as he understands these through the potential of hip-hop 'creation'.

\section{Telling musical stories}

A number of researchers have argued that rap music provides an artistic form of lyrical storytelling, and operates as a means of countering negative stereotypes and contesting dominant cultural stories told about young people (Dimitriadis 2001a, Mahiri and Conner 2003, Neate 2003, Rose 1994). That is, rappers articulate a kind of collective story through song. According to Laurel Richardson, 'at the group level, collective stories help overcome the isolation and alienation of contemporary life and link disparate persons into a collective consciousness' (1997:59). In a similar sense, music making can be understood as offering, in terms of Ruth Finnegan's (1989) concept of "urban pathways," ways in which people find meanings in social spheres where they can control things, creating pathways through urban life by means of musical artistry and community.

These notions - musical practices as collective storytelling and urban pathways - are evident in the first track created and recorded by a student in the programme, a song by MC Novakane (age 19). As in later sessions (described above) with Patches, Novakane and I began by sitting together and chatting about our lives, then discussing how we could go about creating a song with the software. Novakane had already written the lyrics - during a recent stint in jail — and he pulled a crumpled sheet of paper from his pocket and began to rehearse his lines to those of us within earshot, swivelling somewhat nervously in his chair. This was the first song he had ever made, and he had decided that he wanted to create a dark, brooding musical mood. For this, he had already identified Bruce Springsteen's song The Streets of Philadelphia to sample to create the backing track. We loaded Springsteen's song into an audio editing programme, selected the first four measures (before Springsteen starts singing), slowed them down slightly, and then saved the sample into a separate file for our own use. Building on this looped audio sample, in a different software programme I showed Novakane how to synthesize and layer in additional percussion, and when he was sufficiently satisfied with his results, he said he was ready to record his rap, which he called My Natives. We opened up the sequencing/recording software, plugged the microphone into the back of the computer, and he recorded the song on the first take, in front of the rest of our group of six. We sat in awed silence as he sang into the microphone, still swivelling in his chair:

This is for my Natives, my players, my Natives...Someone get me off of this shit...

My heartbeat's a scream, to know this is just a dream

The teardrop's my eye, the weed helps me fly

Mama always told that life brings the wild

I can't stop thinking will I ever hold a child?

Got homeys in the cage always counting the days

Burn a little sage to complete my prayers

To be honest with the truth, I wanna help the youth

The reservation like a 'hood, my rhymes are me and you

Why am I drinking, always thinking 'What's wrong?' 
Givin' a little a heart and keepin' myself strong,

In my mind I'm a chief, for real I got some beats,

I wanted to be the man to knock out Custer's teeth.

Give me a holler I'll show the world I care,

From redskins to black get me off this welfare,

Creator all I ask is embrace me with a hug,

To my people from me to you, would you pray for a thug?

So let me say this once, to death I'm a soldier,

Hold back my pocketbook, the world's getting colder,

For real, Native, listen to what I told ya,

For any Native ladies dressing babies let me hold ya.

Right and wrong, is 24/7,

And if I die, and which I will, it stays in heaven,

So all I really know is are you down with me?

Give me your hand, and I'll be taking back this land,

Yeah, my Natives... uh uh uh, my Natives... my Natives... Come on... my Natives.

\section{Conclusion}

Through composition and performance, such as MC Novakane's rap, music making in The Beat of Boyle Street became part of powerful, meaningful representational practices that built upon the hip-hop knowledge and artistry that this group of young Aboriginal people brought to the project. The poet Maya Angelou has explained the power and relevance of creating and sharing poetry and stories through rap:

lyrical poetry is out for the time being, and something that is called rap or hip-hop is in. It is still poetry, and we can't live without it. We need language to tell us who we are, how we feel, what we're capable of - to explain the pains and glory of our existence... we are characterized by the need to create stories, songs, and poems, and we continue to create. (Angelou n.d.)

These lines connect the power of rapping and the importance of sharing stories. As a research method and metaphor, musical remix practices allowed me to tune into and better understand the worldviews of young Aboriginal people in ways that other research techniques may not have offered. The young people shared through song what they knew about hip-hop and Aboriginal cultures, and I shared my production skills in support of their creative endeavors. It is through this exchange that I believe the arts of the remix can occur with most impact. Arguably, much can be learned about youth musical cultures from listening to texts such as songs and lyrics. However, entering into participatory processes of making music, as in The Beat of Boyle Street, provided me with a means of developing relevant, respectful and reciprocal relationships with young people, relationships that unfolded through stories and were woven through the music. 


\section{References}

Angelou, Maya. (n.d.). Hip Hop Congress. Available at http://hiphopcongress.com/expression/poetry/poetry archive angelou.html (accessed 13.06.06).

Bennett, Andy. 2003. The use of 'insider' knowledge in ethnographic research on contemporary youth music scenes. In Researching Youth (eds) Andy Bennett, Mark Cieslik and Steven Miles, 186-200. London: Palgrave.

Bennett, Andy. 2005. Editorial: popular music and leisure. Leisure Studies 24(4), 333 342.

Bochner, Art. P. and Carolyn Ellis. 2003. An introduction to the arts and narrative research: art as inquiry. Qualitative Inquiry 9(4), 506-514.

Cohen, Phil and Pat Ainley. 2000. In the country of the blind? Youth studies and cultural studies in Britain. Journal of Youth Studies 3(1), 79-95.

Cutler, Chris. 1995. Plunderphonics. In Sounding Off! Music as Subversion/ Resistance/Revolution (eds) Ron Sakolsky and Fred Wei-han Ho, 67-86. New York: Autonomedia.

Dimitriadis, Greg. 2001a. 'In the clique': popular culture, constructions of place, and the everyday lives of urban youth. Anthropology \& Education Quarterly 32(1), 29-51.

Dimitriadis, Greg. 2001b. Coming clean at the hyphen: ethics and dialogue at a local community center. Qualitative Inquiry, 7(5), 578-597.

Efron, Sarah. 2001. Native hip-hoppers rap out their message. The Georgia Straight 31.05.01. Available at www.sarahefron.com/stories/tribalwizdom.shtml (accessed 21.06.06).

Finnegan, Ruth. 1989. The Hidden Musicians: Making Music in an English Town. Cambridge: Cambridge University Press.

Fiske, John. 1989. Understanding Popular Culture. London: Routledge.

Giroux, Henry A. 1992. Border Crossings: Cultural Workers and the Politics of Education. London: Routledge.

Hollands, Robert. 2004. Rappin' on the reservation: Canadian Mohawk youth's hybrid cultural identities. Sociological Research Online 9(3), available at www.socresonline.org.uk/9/3/hollands.html (accessed 21.09.04).

Lashua, Brett D. 2005. Making Music, Re-making Leisure in The Beat of Boyle Street. Unpublished PhD dissertation. University of Alberta.

Lipsitz, George. 1994. We know what time it is: race, class, and youth culture in the nineties. In Microphone Fiends: Youth Music \& Youth Culture (eds) Andrew Ross and Tricia Rose, 17-28. London: Routledge.

Mahiri, Jabiri and Erin Conner. 2003. Black youth violence has a bad rap. Journal of Social Issues 59(1), 121-140.

Neate, Patrick. 2003. Where You're At: Notes from the Frontline of a Hip Hop Planet. London: Penguin Books. 
Richardson, Laurel. 1997. Fields of Play: Constructing an Academic Life. New Brunswick, NJ: Rutgers University Press.

Rojek, Chris. 2005. P2P leisure exchange: net banditry and the policing of intellectual property. Leisure Studies 24(4), 357-369.

Rose, Tricia. 1994. Black Noise: Rap Music and Black Culture in Contemporary America. Hanover, NH: University Press of New England.

Sakolsky, Ron. 1995. Boyz from the rez: an interview with Robby Bee. In Sounding Off! Music as Subversion/Resistance/Revolution (eds) Ron Sakolsky and Fred Wei-han Ho, 163-170. New York: Autonomedia.

Statistics Canada. 2001. Aboriginal Peoples of Canada. Available at www12.statcan.ca/english/census01/products/analytic/companion/abor/canada .cfm (accessed 23.03.05).

Sweetman, Paul. 2001. Stop making sense? The problem of the body in youth/sub/counter-culture. In Exploring the Body (eds) Sarah CunninghamBurley and Kathryn Backett-Millburn, 183-200. London: Palgrave.

Théberge, Paul. 1997. Any Sound You Can Imagine: Making Music/Consuming Technology. London: Wesleyan University Press.

Tomlinson, Alan. 2006. Leisure studies: progress, phases and possibilities - an interview with Alan Tomlinson. Interviewed by David Andrews. Leisure Studies 25(3), 257-273.

Willis, Paul. 2000. The Ethnographic Imagination. London: Routledge.

\section{Acknowledgements}

I would like to thank the students and staff at Boyle Street Education Centre for their creative participation and support in The Beat of Boyle Street. Special thanks to Dr Karen Fox for her inspiration, thoughtful provocation, and wonderful guidance of my doctoral work. I am also grateful to the Editor and two anonymous reviewers, as well as Dr Susanne Langer of Cardiff University, for the constructive comments and suggestions all have made across several drafts of the paper.

\section{About the author}

Brett Lashua studied leisure at the University of Alberta (Canada) where he completed his doctorate (2005), entitled 'Making music, re-making leisure in The Beat of Boyle Street'. He is currently a Research Associate with Cardiff University's School of Social Sciences, where he conducts walking tours and creates soundscapes with young people through an ESRC-funded project called 'Locality, Biography \& Youth in a Transforming Community' (with Tom Hall and Amanda Coffey). His interests are primarily leisure, youth, popular culture, music and soundscape, particularly as these inform questions of creativity, representation and identities. $\mathrm{He}$ can be reached at LashuaB@cf.ac.uk 